\title{
Kiriopascha w tradycji liturgicznej Kościoła prawosławnego
}

\author{
ks. Adam Magruk \\ Chrześcijańska Akademia Teologiczna w Warszawie (Wydział Teologiczny) \\ Prawosławne Seminarium Duchowne w Warszawie, Polska \\ ORCID: 0000-0001-9468-624X \\ admagruk@wp.pl
}

rev. A. Magruk, Kiriopascha in the liturgical tradition of the Orthodox Church, Elpis, 22 2020: 91-xx.

\begin{abstract}
The following article deals with the issue of "Kiriopascha". This term indicates a situation in which the Sunday of the Resurrection will fall on March 25, i.e. the day when the Orthodox Church remembers the Annunciation of the Mother of God. The article describes the issue of establishing the date of the above-mentioned feast and its relation to Christ's Passover. In addition, the order of worship which is characteristic of the case of Kiriopascha was also presented.
\end{abstract}

\begin{abstract}
Streszczenie: Poniższy artykuł dotyczy zagadnienia „Kiriopaschy”. Nazwa wskazuje na sytuację, w której niedziela Zmartwychwstania Pańskiego przypadnie na 25 marca tj. dzień, w którym Kościół prawosławny modlitewnie wspomina Zwiastowania Bogurodzicy. W artykule poruszono kwestię ustanowienia daty wspomnianego Theotokarnego święta oraz jej relacji w odniesieniu do Chrystusowej Paschy. Przedstawiono ponadto porządek nabożeństwa, który cechuje przypadek Kiriopaschy.
\end{abstract}

Keywords: Kiriopascha, Passover, Annunciation of the Mother of God, service, feast

Słowa kluczowe: Kiriopascha, Pascha, Zwiastowanie Bogurodzicy, nabożeństwo, święto

\section{Wstęp}

Zmartwychwstania Chrystusa jest najważniejszym świętem w prawosławnym roku liturgicznym. Św. Jan z Damaszku w kanonie jutrzni tego dnia tytułuje je ,świętem świąt i uroczystością nad uroczystościami” (Trio-

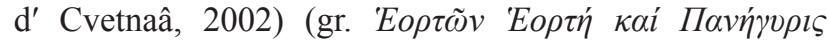

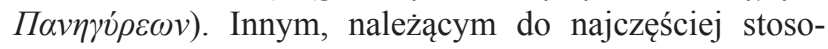
wanych określeń wspominanego wydarzenia należy termin „Pascha” (z hebr. przejście, wyjście). Nazwa odnosi się do Starotestamentowego epizodu, upamiętniającego uwolnienie Izraelitów z niewoli egipskiej i ich wyjście do Ziemi Obiecanej. Chrześcijaństwo z kolei interpretuje je przez pryzmat Chrystologiczny. Swoim zwycięstwem nad śmiercią Syn Boży pokazuje człowiekowi drogę przejścia ze śmierci do życia, od grzechu do łaski, od smutku do prawdziwej radości i nadziei.

Zgodnie z postanowieniem I Soboru Powszechnego w Nicei z 325 r. ${ }^{1}$, Pascha ma być wspominana liturgicznie w niedzielę, następującą po pierwszej wiosennej pełni księżyca, która rozpoczyna się $\mathrm{w}$ dniu lub po wiosennej równonocy, nigdy jednak wspólnie lub przed Paschą Żydowską. W praktyce oznacza to, że Wielkanoc jest świętem ruchomym.

\footnotetext{
Ks. Marek Ławreszuk, powołujący się na prof. Bołotova, zauważa, że nie istnieją historyczne świadectwa dotyczące istnienia tego typu postanowienia. Zdaniem rosyjskiego liturgisty Ojcowie I Soboru Powszechnego mogli przyjąć ustne postanowienie, aby dzień paschalny świętować zgodnie z wyliczeniami Kościoła Aleksandrii. (Marek Ławreszuk, 2012, s. 222-223).
}

W sytuacji, kiedy Zmartwychwstanie Pańskiego wypadnie 25 marca, wówczas nosi ono nazwę „Kiriopascha”. Pierwszy człon tego wyrazu wskazuje na grecki termin кúplos, które dosłownie tłumaczy się m.in., jako „prawdziwy”, ,rzeczywisty”, „realny”, ,prawowierny”.

W czym zatem zawiera się ,,autentyczność" połączenia Paschy ze Zwiastowaniem Bogurodzicy? Jak wygląda prawosławny porządek liturgiczny tego dnia? Próba odpowiedzi na te pytania zostanie zaprezentowana w poniższym artykule.

\section{Data święta Zwiastowania Bogurodzicy i jego relacja z Paschą Pańską}

25 marca Kościół prawosławny obchodzi Zwiastowa-

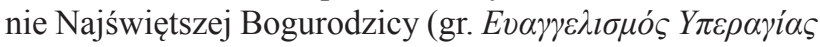
$\Theta \varepsilon о \tau o ́ \kappa o v)$. Należy ono do największych świąt z cyklu dwunastu największych (cs. двунадесятый праздник). Początki jego obchodów sięgają nie później niż VI-VII w. $Z$ tego okresu bowiem pochodzą homilie przeznaczone na ten dzien autorstwa m.in.: św. Grzegorza Cudotwórcy

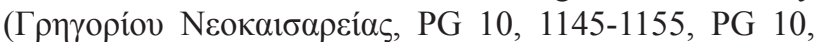
1156-1171, PG 10, 1171-1176), św. Proklusa Konstanty-



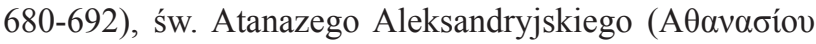
A $\lambda \varepsilon \xi \alpha v \delta \rho \varepsilon i ́ \alpha \varsigma$, PG 28, 917-944) oraz św. Bazylego z Seleucji (В $\alpha \sigma i ́ \lambda \varepsilon 10 \varsigma$ $\Sigma \varepsilon \lambda \varepsilon v \kappa \varepsilon i ́ \alpha \varsigma$, PG 85, 425-452). 
$\mathrm{Na}$ przestrzeni historii pojawiło się co najmniej kilka wyjaśnień wyboru daty tego Theotokarnego święta. Św. Jan z Nicei głosił, że wydarzenie Zwiastowania musiało mieć miejsce wiosną, a dokładniej w miesiącu Nissan (wg porządku kalendarza Gregoriańskiego wypada on na marzec -kwiecień). Nie konkretyzuje jednak którego dokładnie dnia

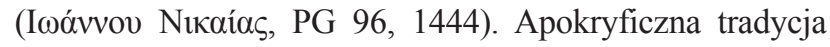
z kolei nie odrzuca możliwości datowania pierwszego dnia stworzenia 25 marca. Z tego właśnie względu św. Anastazy Antiocheński pisze, że marcowy period cechuje zewsząd zauważalny fenomen odrodzenia natury po zimowym odpoczynku. Jego zdaniem dzieje się tak dlatego, że otaczająca człowieka przyroda przypomina mu o tym, że w tym właśnie czasie Bóg powoływał do istnienia Swoje stworzenie. Stąd też Syn Boży staje się człowiekiem „Drugim Adamem" w tym samym czasie, co Praojciec ludzkości w raju

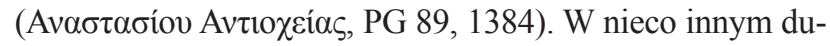
chu wyraża się św. Atanazy Wielki, w opinii którego, Druga Osoba Świętej Trójcy zamieszkała w łonie czystej Dziewicy 25 marca, tj. dokładnie w tym samym czasie, kiedy Bóg stworzył pierwszego człowieka (A $\theta \alpha v \alpha \sigma i ́ o v ~ A \lambda \varepsilon \xi \alpha v \delta \rho \varepsilon i \alpha \varsigma$, PG 28, 632). Z kolei autor „Synaksarionu” na święto Zwiastowania Bogurodzicy, jest zdania, że Bóg stworzył świat w marcu, a dokładnie 25 jego dnia, ponieważ wówczas Adam miał być zwiedziony obietnicą węża. Naruszywszy tym sposobem Boże przykazanie upadł, po czym został wygnany z raju (Hieromnich Makary, 2016). Inny przekaz mówi o tym, że w tym właśnie miesiącu Naród Wybrany wyszedł z Egiptu i niczym po suchym lądzie przeszedł przez Morze Czerwone (Hieromnich Makary, 2016).

Jeszcze do II w. 25 marca traktowany był jako dzień wiosennego zrównania dnia z nocą (Rogobete, 2009). $\mathrm{Z}$ jednej strony, bezpośrednio wiążące się z okresem przesilenia wiosennego Zwiastowanie jest czasem, kiedy ciemność nocy zaczyna ustępować miejsca światłości dnia. Syn Boży, Który zstępuje na ziemię, niejako odwracając ruch czasu, zaś historia od zstępowania do śmierci dokonała definitywnego wstępowania do niekończącej się wiosny (Hieromnich Makary, 2016). Z drugiej jednak strony, równa ilość godzin dnia i nocy posiadała doskonałe odniesienie do Osoby Chrystusa - doskonałego Boga i równie doskonałego człowieka.

Około 100 lat później Hipolit Rzymski będzie mówił o 25 marca, jako dniu ukrzyżowania Chrystusa (Kaškin, 2017). Myśli tej wtóruje Tertulian. Łaciński teolog sądzi, że mniej więcej w tym samym czasie 23 marca zaczęto wspominać krzyżową śmierć Zbawiciela, zaś dwa dni później Jego chwalebne zmartwychwstanie. Informacja ta jest najbardziej starożytną wzmianką, bezpośrednio odnoszącą się do ścisłego związku, jaki zachodzi pomiędzy świętem Zwiastowania i Chrystusową Paschą.

Jezus umarł 25 marca również w przekonaniu św. Jana Chryzostoma. Do Konstantynopolitańskiego hierarchy należy też pierwsze użycie pojęcia „Kiriopascha”. Stosuje on je w Homilii na dzień Zmartwychwstania 27 marca z 387

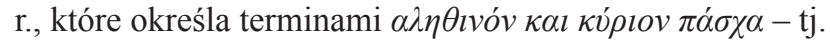

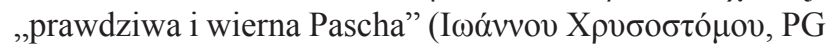
$59,751)$.
Żyjący na przełomie IV i V w. biskup Rimisiany Nicetas twierdził, że Zbawiciel powstał z martwych w trakcie trwającej równonocy wiosennej, podczas pełni księżyca w niedzielę, która odnosiła się jednocześnie do pierwszego dnia stworzenia świata (Rogobete, 2009).

W V w. pojawiła się zaś tendencja do wspólnego świętowania poczęcia Jezusa wraz $\mathrm{z}$ wielkopiątkową męką (Kaškin, 2017). Jednym z prekursorów tej myśli był m.in. błogosławiony Augustyn (Za: Rogobete, 2009). Nie inaczej sądził rzymski mnich i teolog Dionizy Mały (V/VI w.): „ósma kwietniowa kalenda wskazuje na datę, kiedy dzień równy jest nocy. Tego też dnia Gabriel zwiastuje Dziewicy Marii dobrą nowinę, mówiąc: «Duch Święty zstąpi na Ciebie i moc Najwyższego osłoni Ciebie». Dlatego narodzony z Ciebie Synem Bożym nazwany będzie. Tego samego dnia cierpiał Chrystus swoim ciałem" (Dionysii Exigui, PL 67, 506).

O 25 marca, jako pierwszym dniu stworzenia świata i zarazem wielkanocnym, wzmiankują również Georgios

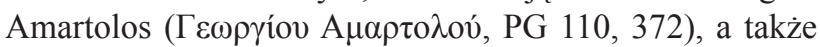

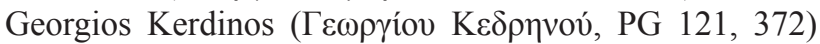
w swoich bizantyjskich kronikach, datowanych na VII w. (Rogobete, 2009). Pogląd ten po części zdaje się podzielać, żyjący około 100 lat później św. Piotr Damasceński. Według syryjskiego ascety i pisarza, skoro wszystkie największe wydarzenia z życia Jezusa, które Kościół wspomina w swoim heortologione w rzeczywistości miały miejsce w niedzielę, to również wcielenie Logosu z całej pewności

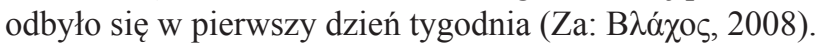
I chociaż nie mówi on dokładnie o święcie Zmartwychwstania, to jego opinia zbliżona jest w tym aspekcie do wyżej wymienionych, zważywszy na fakt, iż każda niedziela roku liturgicznego określana jest „Małą Paschą”.

Warto dodać, że jeszcze w X w., zamieszkujący obecne tereny Rosji wierni przywiązywali do wspólnego świętowania Zwiastowania i Paschy ogromne znaczenie. Powszechną była świadomość - oparta zresztą na apokryficznych przekazach - iż rok, w którym wypadnie Kiriopascha, będzie jednocześnie czasem powtórnego przyjścia Chrystusa (Danilevskij, 1998). Ta sama, odważna teoria pojawia się w cytowanym już powyżej „Synaksarionie” mnicha Makarego, który również mógł bazować na tego typu pozakanonicznych źródłach (Hieromnich Makary, 2016).

Jak zaobserwowano, wśród wyżej wymienionych opinii teologicznych dominuje ta, która bezpośrednio koreluje datę Zwiastowania Bogurodzicy z dniem Wielkanocy. Tradycja cerkiewna stosuje określenie „Kiriopascha” w odniesieniu do wydarzenia Zmartwychwstania Chrystusa, które w czasie Jego miało się dokonać dokładnie w tym samym dniu miesiąca co Jego poczęcie w łonie Czystej Dziewicy. Stąd użycie pierwszego członu tego pojęcia kópıov, które przypominać ma tę niezwykłą zbieżność, która dokonała się ponad 2000 lat temu.

Niezwykle istotnym jest zaakcentowanie w tym miejscu, że nie do końca prawidłowe jest tłumaczenie słowa „Kiriopascha” jako „Pascha Pańska” (Lebedev, 1905). Wynika to z prostego faktu, iż przymiotnik ,,pański” w starej

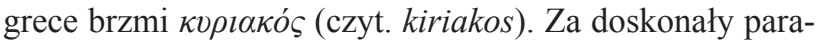


dygmat w tej kwestii posłużyć mogą dwa nowotestamento-

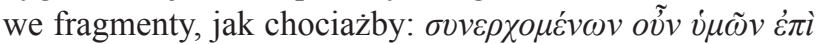

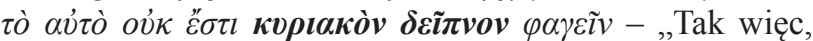
gdy się zbieracie, nie ma u was spożywania Wieczerzy

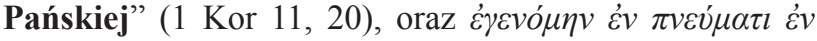

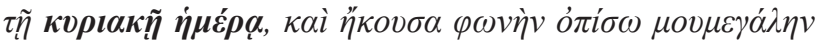

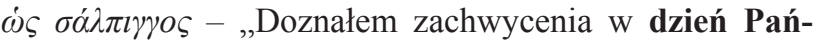
ski i posłyszałem za sobą potężny głos jak gdyby trąby" (Ap 1,10). Termin, o którym mowa może również zostać przetlumaczony, jako dopełniacz rzeczownika $o$ кúplos - „pan”, „władca”, zapisywany w sposób następujący: tov kvpiov (czyt. tou kiriou). Ten wariant z kolei stosuje w kanonie jutrzni święta Paschy jego autor - św. Jan Damasceński - który „Paschę Pańską” oddaje jako „Kvpíov

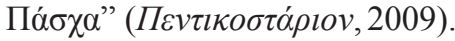

Aleksandryjskie paschalia przewidują świętowanie Kiriopaschy 12 razy na przestrzeni Wielkiego Indyktionu tj. 532 lat, co w praktyce oznacza maksymalnie 3 razy na 100 lat. Ostatni taki przypadek miał miejsce w 1991 r., zaś następny wyznaczony został na $2075 \mathrm{r}$.

\section{Porządek nabożeństwa Kiriopaschy}

Unikalność Kiriopaschy przejawia się w szczególny sposób również pod względem liturgicznym. W sytuacji, kiedy w dniu Zmartwychwstania Chrystusa wypada jakiekolwiek święto bądź też pamięć świętego, wówczas teksty nabożeństw im poświęconych nie są w ogóle czytane. Pascha Pańska przewyższa wówczas liturgiczne wszystkie inne wydarzenia roku Kościelnego. Jedyny wyjątek od tej reguły stanowi święto Zwiastowania Najświętszej Bogurodzicy. Typikon Atoskiego Monasteru Filotheou przestrzega nawet, że przeniesienie tego święta z Wielkiego Tygodnia, samej Paschy lub tygodnia paschalnego na którykolwiek inny dzień roku jest ,wielkim naruszeniem reguły (gr. $\pi \alpha \rho \alpha v o \mu i \alpha)$ oraz herezją". Autor zapisu thumaczy tę uwagę faktem niedopuszczalnego naruszenia w najmniejszym stopniu idealnego dziewięciomiesięcznego okresu ,przebywania" Zbawiciela w łonie Bogurodzicy (Rogobete, 2009).

W klasztorze św. Dionizego na Olimpie z kolei, w sytuacji Kiriopaschy praktykowano sprawowanie aż dwóch oddzielnych nabożeństw. W pierwszej kolejności późnym wieczorem Wielkiej Soboty odprawiano jutrznię Zwiastowania i dopiero po jej zakończeniu rozpoczynano tradycyjne czy-

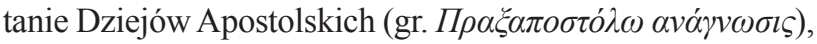
po czym rozpoczynało się nabożeństwo o północy (cs. Полунощнищуа) і Paschalna jutrznia (Rogobete, 2009).

Podobny ryt przewidywała tradycja konstantynopolitańska. Typikon Hagii Sophii zakładał wówczas procesję od najważniejszego placu stolicy Bizancjum tzw. Forum Kon-

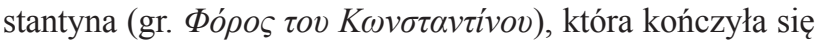
w świątyni poświęconej Bogurodzicy o nazwie Chalkopra-

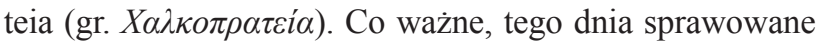
były dwie liturgie: jedna pod przewodnictwem patriarchy w Hagii Sophii i druga celebrowana przez jednego z duchowych cerkwi Chalkoprateia (Rogobete, 2009).

Porządek nabożeństw obecnej tradycji liturgicznej, tego jedynego w swoim rodzaju przypadku, określa księga Typikonu w rozdziale 48 pod datą 25 marca i tytułem: Подобает ведати, яко аще случится в самую святую и великую неделю Пасхи, еже есть Кириопасха, праздник Благовещения Пресвятыя Богородищьы - „Należy wiedzieć, że kiedy święto Zwiastowania Przenajświętszej Bogurodzicy obchodzone będzie w najświętszą i wielką niedzielę Paschy, tj. Kiriopaschę (wówczas)" (Tipikon, 1896), po czym zanotowano prawidłową kolejność jej poszczególnych elementów składowych.

Poniżej wskazano jedynie najbardziej charakterystyczne momenty, które odróżniają nabożeństwo Kitiopaschy od „zwykłej” Paschy.

W Wielką Sobotę podczas wielkiej wieczerni, która zwyczajowo połączona jest z Liturgią św. Bazylego Wielkiego, recytowanych jest 10 sticher: 3 zmartwychwstaniu, 3 Wielkiej Soboty i 4 święta Zwiastowania, na "Chwała" Wielkiej Soboty, zaś na „I teraz” Zwiastowania. Do przewidzianych na ostatni dzień Wielkiego Tygodnia 15 starotestamentowych fragmentów (cs. nаримиe) dołącza się aż 5 święta Zwiastowania. Podczas nabożeństwa o północy, czytany jest w pierwszej kolejności kanon Zwiastowania z 6 troparionami i Wielkiej Soboty z 8 troparionami. Katabasia zaczerpnięta została $\mathrm{z}$ Wielkosobotnich hirmosów. Po 3 pieśni wygłaszane są kondakion i ikos Zwiastowania, siedalen natomiast odnosi się już do Wielkiej Soboty. Po 6 pieśni z kolei zabrzmią wyłącznie wielkosobotnie: kondakion i ikos. Po zakończeniu 9 pieśni kanonu następuje recytacja Trysagionu, a po modlitwie Pańskiej śpiewane są tropariony: „Kiedy zstąpiłeś (...)” oraz „Dzisiaj zbawienia naszego początek (...)”.

Początek paschalnej jutrzni pozostaje bez zmian do momentu wejścia do świątyni. Po przekroczeniu przez duchownych progu prezbiterium, śpiewany jest trzykrotnie troparion Zwiastowania. W trakcie nabożeństwa wygłaszany jest kanon Paschy z hirmosem na 8 troparionów oraz Zwiastowania również z hirmosem na 8 troparionów. Po 3 pieśni następuje kondakion, ikos i ipakoi Paschy. Zgodnie z zaleceniem Typikonu w tym miejscu powinna być czytana „45 Homilia św. Grzegorza Teologa na dzień Świętej Paschy”, zaś po zakończeniu 6 pieśni kondakion i ikos święta Zwiastowania. W tradycji greckiej jest to miejsce, gdzie czyta się Synaksarion Paschy. Warto pamięć, że w przypadku Kiriopaschy, w tym właśnie momencie przychodzi kolej na prokimenon święta Zwiastowania: „Głoście z dnia na dzień zbawienie Boga naszego” oraz lekturę Ewangelii wg św. Łukasza (Łk 1, 39-49. 56). Po jej zakończeniu śpiewane jest trzykrotnie: „Zmartwychwstanie Chrystusa widząc (...)”, a także sticherę: „Zmartwychwstał Jezus (...)”. W trakcie 9 pieśni, obok paschalnych brzmią również stychosy Zawiastowania. Ta sama zasada dotyczy również eksapostilarionu, z tą jednak różnicą, iż paschalny będzie śpiewany jeden raz, natomiast święta Zwiastowania dwa razy.

Podczas recytacji psalmów pochwalnych do 4 niedzielnych sticher dodawanych jest 4 Zwiastowaniu z odpowiednimi stychosami. Godnym uwagi jest włączenie na "Chwała” do tzw. sticher Paschy (,Niech powstanie Bóg i niech rozproszą się wrogowie Jego...”) tekstu, odnoszącego się do Zwiastowania, rozpoczynającego się on od słów: „Niechaj 
weselą się niebiosa i raduje się ziemia...". W następnej kolejności kolejne części jutrzni podążają swoim rytmem, bez dodatkowych elementów śpiewane są też godziny paschalne.

Świąteczna Liturgia św. Jana Chryzostoma przewiduje dodanie podczas „Małego Wejścia” do paschalnego porząd$\mathrm{ku}$, troparionu Zwiastowania Bogurodzicy po trzykrotnym: „Chrystus powstał z martwych, śmiercią podeptał śmierć i tym, co w grobach życie darował". Czytane są ponadto po dwa prokimenony, lekcje apostolskie i czytania ewangeliczne: najpierw Paschy, a następnie święta Zwiastowania. Ostatnim akcentem Kiriopaschy, podczas tego nabożeństwa jest theotokarny koinonikon, który zabrzmi tuż po wyznaczonym na ten dzień jego paschalnym odpowiedniku.

\section{Zakończenie}

Cały marzec (gr. Mó $\rho \tau \imath o \varsigma)$ nie tylko swoją nazwą (od

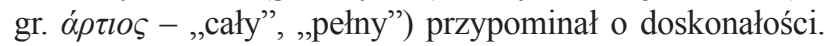
Jak zaobserwowano, niemal od samego początku skupiał on w sobie najważniejsze tajemnice Bożej ekonomii, począw- szy od stworzenia świata i wcielenia Logosu, Jego krzyżowej śmierci, a skończywszy na sądzie ostatecznym oraz odrodzeniu całego stworzenia. To właśnie z uwagi na symboliczny charakter 25 marca - zgodnie z prawosławnym porządkiem liturgicznym - nie może być przeniesione na inny dzień, nawet w sytuacji, kiedy wypadnie ono w Wielkim Tygodniu oraz dniu Paschy (Hieromnich Makary, 2016).

Wspólne wspomnienie Paschy i Zwiastowania, bez wątpienia niesie ze sobą obietnicę pełni, która odnosi się do całego świata. M. Quenot ujmuje to zagadnienie w takich oto głębokich słowach: ,W zderzeniu światłości z ciemnością, co unaocznia historię zbawienia, wyróżniają się trzy fazy: światłość pozostaje ukrytą od Zwiastowania, które przygotowuje zwycięstwo i stanowi pierwszy element paschalny; po raz pierwszy światłość rozdziera ciemności w Narodzeniu, aby następnie wszystko zalać światłością w dniu Zmartwychwstania” (Quenot, 2001).

Kiriopascha stanowi absolutnie wyjątkowe połączenie płaszczyzny teologicznej i liturgicznej. Z całą pewnością to właśnie dlatego niemal zawsze spotyka się ono z osobliwą uwagą i zainteresowaniem.

\section{Bibliografia}

Hieromnich Makary. (2016). Synaksarion. Żywoty świętych Cerkwi Prawosławnej spisane na Świętej Górze Atos. Hajnówka: Bratczyk.

Ławreszuk, M., ks. (2012). Paschalia Kościoła Prawosławnego: metody obliczania daty Paschy. Elpis, 14 (2012), 217-277.

Quenot, M. (2001). Zmartwychwstanie i ikona. Białystok: Orthdruk.

Danilevskij, I. N. (1998). Drevnââ Rus' glazami sovremennikov $i$ potomkov (IX-XII vv.). Moskva [Данилевский, И. Н. (1998). Древняя Русь глазами современников и потомков (IX-XII вв.). Москва].

Dionysii Exigui. Argumenta Paschalia. PL 67. 497-508.

Kaškin, A. (2017). Liturgika. Dvunadesâtye nepodvižnye prazdniki, t. 1. Saratov: Saratovskaâ Mitropoliâ [Кашкин, A. (2017). Литургика. Двунадесятые неподвижные праздники, t. 1. Саратов: Саратовская Митрополия].

Lebedev, D.A. (1905). Počemu prazdnik Pashi 25 marta nazyvaetsâ "Kiriopasha". Bogoslovskij vestnik. t. 2. nr 5. 118-128 [Лебедев, Д.А. (1905). Почему праздник Пасхи 25 марта называется «Кириопасха». Вогословский вестник. t. 2. nr 5. 118-128].

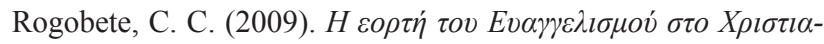

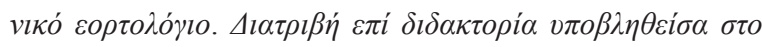

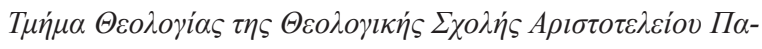

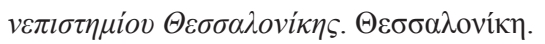

Tipikon, siest ustav. (1896). Moskva [Типикон, сиест устав. (1896). Москва].

Triod' Cvetnaâ. (2002). Moskva:Izdatel'skij Sovet Russkoj Pravoslavnoj Cerkvi [Триодь Цветная. (2002). Москва: Издательский Совет Русской Православной Церкви].



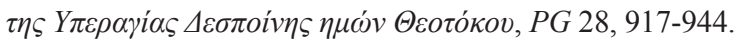

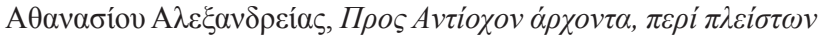



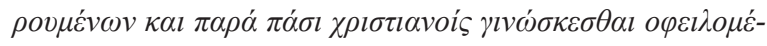

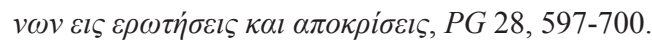

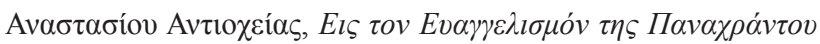

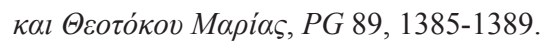

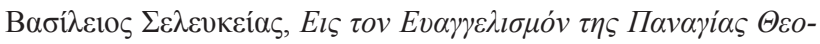
то́коv, $P G 85,425-452$.

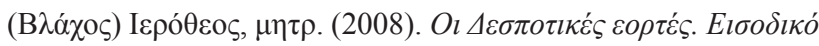



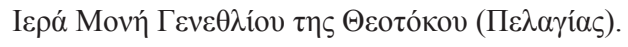

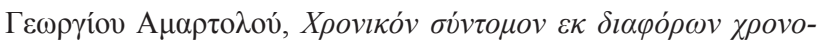

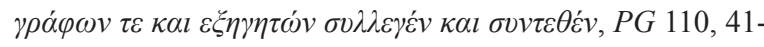
1285.

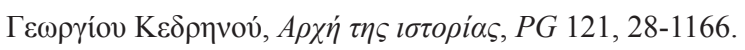

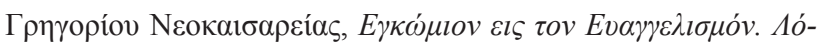

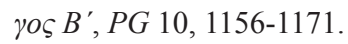

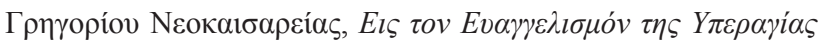

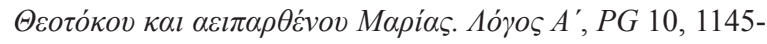
1155.

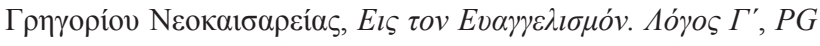
10, 1171-1176.

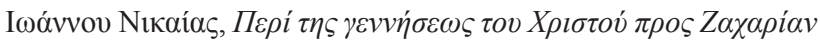

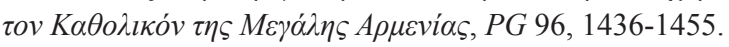


745-755.

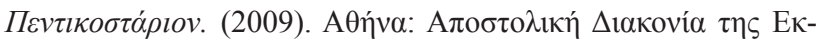
$\kappa \lambda \eta \sigma i \alpha \varsigma \tau\rceil \varsigma$ E $\lambda \lambda \alpha \dot{\delta} \delta \varsigma$.



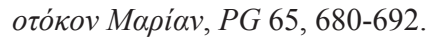

Rozmiar artykułu: 0,6 arkusza wydawniczego 